\title{
SENI: WAHANA UNTUK MENAJAMKAN RASA DAN MEMINTARKAN EMOSI
}

\author{
Niken Iriani LNH \\ Universitas Muhammadiyah Surakarta
}

\begin{abstract}
Intisari
Dengan seni, orang bebas mengekspresikan diri, mengenali dan memahami emosi diri dan orang lain. Melalui ekspresi emosi dan seni orang belajar empati dan menempatkan diri. Sikap seperti ini menpakan salah satu modal untuk berperilaku serba pas secara sosial. Kemampuan berperilaku pas secara sosial ini merupakan kemampuan bergaul yang baik, salah satu ciri dari dimilikinya kecerdasan emosi. Oleh karena itu secara lidak langsung, seni berperan untuk menajamkan rasa dan memintarkan emosi. Seni dapa mengutuhkan dan memanusiawikan manusia sekaligus memperkaya batin dan mengasah akal.
\end{abstract}

Kata kuncl: Seni, ekspresi, media ekspresi

Niken Irlani, lahir pada 7 Agustus 1962, adalah staf pengajar Fakultas Psikologi Universitas Muharnmadiyah Surakarta. Lulusan S1 (1987) dan $\$ 2$ (1995) Psikologi Universitas Gadjah Mada ini menyukai kajiankajian religiusitas, sosial dan pendidikan.

\section{PENGANTAR}

(R) eberapa waktu lalu kita dibangunkan B oleh Goleman (1997) dengan pernyataannya tentang kecerdasan emosi. b rnenyatakan bahwa ukuran mutu manusia adalah keseimbangan otak dan hati. la telah membuktikan hat itu melalui penelitiannya di Amerika Serikat tentang peran perasaan dan keandalan mengendalikannya sebagai modal hidup sukses personal. Selain itu penelitian yang ia lakukan tersebut juga menegaskan bahwa dunia yang dewasa ini dikuasai oleh kemajuan teknologi mutakhir, makin membuat hubungan antar manusia menjadi rumit. Kerumitan ini menciptakan stres dan kekerasan-kekerasan yang kadang-kadang disebabkan oleh hal-hal yang sepele dan aneh. Tampaknya globalisasi dan kemajuan teknologi yang hebat ini harus dibayar rnahal dengan tumpul atau dungunya perasaan personal. Orang menjadi ce- 
pat marah, individualistik, serba tergesa-gesa dan tidak tumakninah. Manusia menjadi semakin tidak peka dan tidak mampu mendengarkan dan empati terhadap perasaan sendiri dan lebih-lebih orang lain. Emosi, satu aset individu yang kata Goleman akan lebih berperan pada kehidupan mendatang menjadi rusak. Rasanya manusia menjadi tuli dengan perasaan dan emosi sendiri. Yang menjadi pertanyaan adalah bagaimana kecerdasan emosi dan ketajaman rasa tersebut dapat diperaiki.

\section{SENI SEBAGA| EKSPRESI EMOSI}

Dalam kaitannya dengan pencerdasan rasa dan emosi, Goleman menyatakan bahwa sebenamya kemampuan emosi dapat dipelajari dan dikembangkan jika kiła berusana untuk mengajarkannya. Ditambah bahwa pencerdasan emosi tersebut pada dasamya adalah kegiatan budaya atau kegiatan yang secara formal disengaja ada.

Salah satu kegiatan yang strategis untuk diberdayakan dalam rangka pencerdasan emosi adalah seni. Mengapa seni? Karena seni adalah suatu aktivitas yang banyak melibatkan rasa dan emosi. Seni adalah unsur budaya yang amat penting yang memberi wajah manusiawi, keindahan, keselarasan, keseimbangan, perspek tif, irama, harmoni, proporsi dan sublimasi pengalaman manusia pada kebudayaan. Seni merupakan penggambaran berbagai kenyataan dalam beragam pengungkapan yang kreatif. Seni adalah sesuatu yang alamiah dan merupakan upaya mengekspreskan perasaan manusia saat berinteraksi dengan hat hal di luar dirinya seperti Allah, alam, sesama manusia ataupun hewan. Dengan demikian seni merupakan ekspresi emosi yang melibatkan kecakapan akal dan batin manusia dan memiliki unsur-unsur kehaIusan, kepekaan, penikmatnya. Secara psikologis olah rasa atau seni merupakan dan berfungsi sebagai kataris mental, suatu proses pembersihan sistern energi yang terkurung karena pengendalian. Esensi dari katarsis mental itu sendiri sebenarnya adalah ekspresi emosi, dorongan atau kebutuhan untuk mendapatkan sikap dan pandangan yang lebih menyeluruh. Jika seseorang mendapat kesempatan untuk katarsis atau mengungkapan segala kata hati dan perasaan-perasaannya, maka la akan merasakan adanya suatu kelegaan atau suatu perasaan tanpa beban. Kondisi semacam ini secara emosional akan membuat seseorang menjadi lebih santai dan lebih bebas untuk mengekspresikan ide, pendapat maupun keinginan-keinginannya. Dengan kondisi tanpa tekanan seperti ini seseorang akan lebih mampu bertikir secara apa adany a dan obyektif. Melalui katarsis biasanya seseorang akan mendapat sesuatu yang lebih kaya dan berarti.

Pelaksanaan kegiatan seni ini sendiri tidak terlalu sulit, mengingat seni bukan merupakan hal baru lebih-lebih bag dunia penddikan. Oleh karena itu aktivitas seni ini selain bisa diselenggarakan oleh lembaga-lembaga formal seperti sekolah-sekolah atau lembaga-lembaga pendidikan tertentu bisa juga diadakan oleh lembaga non formal seperti misalnya keluarga. Kalaupun selama ini aktivitas seni ini kurang mendapałkan apresiasi secara formal, di antaranya adalah karena seni tersebut tidak mampu memberikan kontribusi yang berharga bagi masyarakat. Hal ini dapat kita perhatikan antara lain mela|ui bermunculannya karya-karya seni yang berharga yang berlindung di balik tameng seni untuk seni, kebebasan berkreasi, kebebasan berimajinasi yang tidak bisa digugat atau diadili. Bisa jadi terhambałnya perkembangan seni itu semata karena dominasi akal atas emosi itu sendiri. Hal ini dapat kita simak dari kenyataan bahwa semenjak seseorang mengenal pendidikan formal, banyak batasan-batasan diberlaku- 
kan bagi kebebasan ekspresi. Ini tercermin dari adanya tata-tertib sekolah, sopan-santun, tatakrama dan lain-lain. Meski demikian dalam batas-batas tertentu, memang berbagai pembatasan tersebut tetap diperlukan sebagai kontrol etik moral. Dengan demikian seni akan memitiki fungsi sosial sebagai alat pengontrol dan penggugah nurani dan rasa keadilan.

\section{JENIS-JENIS SENI}

Jenis-jenis seni yang bisa diajarkan:

\section{Pentama, Gambar}

Kegiatan menggambar dapat menarik perhatian bila diperkenalkan sebagai aktivitas yang dapat dilaksanakan oleh setiap orang. Menggambar merupakan aktivitas yang didukung tidak hanya oleh proses kognitif tetapi juga persepsual dan psikomotor. Menggambar merupakan latihan ketrampilan mengekspresikan diti. Ekspresi kemarahan atau agresi dapat tertuang tanpa konsekuensi merusak lingkungan fisik. Ekspresi ini dapat semakin komunikatif bila seseorang makin mahir menggambar.

Di samping itu menggambar juga merupakan pengenalan dan penuangan ide maupun emosi secara konkret yang biasanya bersifat abstrak. Menggambar juga menungkinkan seseorang memahami bahwa ada ide-ide, perasaan, dan pelukisan, yang hanya dapat dituangkan dalam gambar. Menggambar juga membangun estetik seseorang. Keterlibatan dan pengalaman dalam mengamati, menata dan menuangkan kembali berbagai hal yang dipersepsikan, serta mengevaluasi bentuk, komposisi, warna akan menyebabkan seseorang memiliki selera keindahan.

Selain itu gambar yang diciptakan dapat merupakan simbol dari sesuatu yang sebenarnya. Simbol merupakan abstraksi dari sesuatu yang konkret. Oleh karenanya de- ngan menggambar seseorang mendapat manfaat belajar metakukan abstraksi menjadi simbol di mana simbol-simbol tersebut dapat digunakan sebagai fantasi.

Selain itu, dalam kaitannya dengan seni gambar, seseorang juga bisa dilatih tentang bagaimana menikmati dan memahami serta merasakan gambar orang lain. Melalui cara ini seseorang diajar untuk membaca emosi dan menangkap ide yang diungkapkan orang lain melalui gambar. Gambar berfungsi sebagai alat bantu mengembangkan imajinasi. Dalam kehidupan sosial imajinasi ini penting untuk empati. Sedangkan dalam kehidupan intelektual dan kehidupan sehari-hari imajinasi penting untuk melakukan antisipasi dan perencanaan. Oleh karena itu ketrampilan mengungkapkan dan membaca emosi meralui kegiatan menggambar perlu dilatihkan.

\section{Kedua Kegiatan Menempel dan Karya Tiga Dimensi}

Kegiatan menempel dan membentuk benda, patung dan sebagainya memerlukan lebih banyak ketrampilan jari-jari daripada menggambar. Kegiatan menempel iri seperti kegiatan menggambar lebih efektif bila dilakukan dengan tujuan tertentu. Misainya kegiatan menempel sebagai koleksi realíta hasil perjalanan, di mana perjalanan ini sendiri lebih berkesan dalam ingatan karena tidak dibiarkan berlalu begitu saja. Misalnya ketika bertamasya ke pantai, seseorang tidak hanya duduk pasit, tetapi melakukan eksplorasi untuk menemukan sesuatu yang dapat dipakai sebagai realita. Variasi materi tempel dapa' berupa bahannya, seperti kertas, pasir, bulu ataupun biji-bijian. Warna maupun tekstur pun bisa bermacam-macam seperti bahan yang mengkilat, kasar dan tain-lain. Sedangkan tentang kegiatan karya tiga dimensi, pada prakteknya aktivitas ini jauh lebih rumit dari karya-karya sebelumnya. Karya tiga dimensi dapat dibuat dari berbagai benda padat ditempeli, digambari 
atau dibentuk-bentuk. Misalnya kotak-kotak dapat dibuat menjadi manusia dengan diberi mata, hidung dan mulut, tanah liat (lempung) untuk dibentuk menjadi binatang atau manusia, lego untuk dibentuk sebagai makhluk tertentu dan sebagainya. Manfaat dari aktivitas ini adalah memperkaya pengalaman seseorang bahwa media ekspresi emosi amat beragam.

\section{Ketiga, Ritme dan Musik}

Sejak seseorang masih kecil, ia telah mendengarkan sesuatu yang ritmis. Suarasuara dalam kandungan ibu merupakan suara desiran maupun deguban air yang bergerak dalam ritme. Salah satu pengindraan ritmis yang pernah dialami oleh setiap orang ialah mendengarkan detik jantungnya sendiri. Detak jantung mempunyai pengaruh terhadap kecepatan, tenggang waktu dan dinarnika gerakan seseorang. Kegiatan yang berkaitan dengan ritme dan musik ini bisa dilakukan dengan cara memperkenalkan berbagai macam alat musik sehingga dapat mempertuas cakrawala apresiasi musik. Hal itu dilakukan dengan cara memutar rekaman musik klasik, musik daerah atau yang lain, kemudian membicarakan mengenai suasana hati yang digambarkan atau menceritakan latar belakang musik itu sendiri, Mendengarkan musik kadang-kadang juga bisa menggugah semangat, menggairahkan, menghilangkan ketegangan atau bahkan untuk sementara dapat memberikan suasana tentram. Melalui kegiatan ini seseorang belajar peka terhadap melodi, keras-lembut, dinamika, cepat lambat dan elemen-elemen lain. Yang terkandung dari kegiatan mendengarkan ritme musik ini adalah ketrampilan yang krusial dalam belajar akademik maupun dalam proses hubungan interpersonal.

Berlatih mendengarkan dengan penuh perhatian serta mendiskusikan mengenai berbagai hal yang didengardapat membantu seseorang belajar cara mendengarkan yang diskriminatif dan peka, mengenali perasaan atau suasana hati yang disajikan dan lainlain. Kegiatan lain dari seni ritme musik ini selain mendengarkan adalah memainkan alat musik itu sendiri. Bermain musik merupakan alternatif sarana katarsis bagi seseorang. Sambil bermain musik seseorang bisa mengekspresikan suara hati dan rasa batinnya dengan bebas. la bisa mengatur irama sesuai dengan mood yang dimilikinya. Dengan bermain musik seseorang berlatih mengelola dan mengendalikan emosi.

\section{Koempat, Ritme dan Gerak}

Bergerak adalah mengekspresikan pembebasan dari sesuatu yang tidak enak. Gerak merupakan simbolisasi, displacement maupun katarsis. Bahkan secara ritual, gerak merupakan stuatu sarana mengekspresikan dan mengalihkan ketakutan, kesedihan, kemarahan, kenikmatan, permohonan maupun ampunan. Manusia, terutama anakanak, amat menyukai gerak. Dalam kenyataan banyak anak yang tidak suka diam. Bila gerakan diatur oleh guru, anak sering mengundurkan diri, takut membuat kesalahan. Aktivitas ritme dan gerak ini bisa berupa permainan, tarian, akrobatik maupun pantomim, atau operet. Melalui kegiatan ini seseorang berlath mengembangkan imajinasi untuk membuat suatu harmoni antara ritme dan gerak.

\section{Kelima, Seni Suara}

Biasanya seseorang mulai diajar bernyanyi dengan memperkenal lagu-lagu sederhana yang mudah ditiru. Seseorang cenderung menyenangi lagu-lagu yang dapat dikuti gerakan sebagian badan atau seluruh badan, sesuai dengan syair lagunya. Aktivitas menyanyi banyak berguna bagi kehidupan. Dengan bemyanyi seorang ibu meninabobokkan putranya. Syair yang dilantunkan seringkali sarat dengan pesan atau puji- 
pujian terhadap Sang Pencipta. Ada sernentara ulama mengatakan bahwa dengan se- ring memperdengarkan lagu-lagu pujian pada anak secara perlahan orang tua mengajarkan tauhld ataupun akhlak mulia. Sejak kecil anak dibiasakan mendengarkan halhal yang benar dan indah, hingga pada sazt mereka tumbuh berkembang mereka akan lebih terbiasa dari menyukai kebenaran yang indah. Bagi guru atau siapa saja yang peduli dengan pendidikan, nyanyian atau seni suara yang lain, seni suara membantu mereka menyampaikan pelajaran dan pesanpesan. Anak tertarik untuk mengikuti proses belajar dan menjadi mud ah mengingat apa yang dipelajarinya melalui apa yang indah dldengar. Kemudian, jika anak dilibatkan langsung dengan bernyanyi atau aktivitas seni suara yang lain (qiroatul qur'an), maka ia berlatih mengekspresikan emosi atau suara hati, memahami dar.menghayati apa yang disuarakan seara harmonis. Seni suara memang merupakan altematif kegialan yang mudah dan murah untuk dikuti orang sebagai media katarsis ataupun kontemplasi untuk mempertajam emosi.

\section{Keenam, Seni Sastra}

Bentuk lain mengekspresikan dan mempelajari serta mernahami emosi adalah untuk menuliskan suara hati, keinginan maupun bercerita tentang kehidupannya. Agar tulisan yang dibuat komunikatif, seseorang perlu belajar mengamati secara tajam berbagai peristiwa dan suara sekelilingnya. Dengan menulis seseorang akan dibiasakan bersahabat dan berkomunikasi dengan alam. Lathan ini akan mempertajam intuisinyaSedangkan dengan membaca seseorang dilatih untuk peka terhadap rasa orang lain yang dituangkan dalam tulisan. Dengan membaca tulisan seseorang dilatih untuk mampu membayangkan pesan yang disampaikan. Dengan membaca tulisan seseorang dilatih untuk mendengarkan.

\section{Ketujuh, Seni Peran}

Secara psikologis seni bermain peran mempunyai fungsi terapis yang tidak kecil artinya. Banyak kasus dipecahkan melalui seni bermain peran. Melalui seni bermain peran, seseorang akan menjadi paham dan mengerti sesuatu. Ketika seorang pekerja pabrik bermain peran sebagai manajer, ia jadi paham bahwa menjadi majkan memang tidak gampang dan kadang-kadang harus menjadi pelit dan berkuasa. Sebaliknya, seorang manajer yang bermain peran sebagai buruh, akan mengerti bahwa menjadi pekerja pun tidak ring: in tantangan fisiknya. Karenanya kadang-kadang para buruh mempunyai tuntutan. Karena bermain peran mereka menjadi saling tahu dan saling menghomat. Seri bermain peran merupakan media ekspresi emosi yang kompleks. Di sana banyak imajinasi yang harus dikembangkan, yaitu imajinasi rasa, peran itu sendiri maupun hathal yang menunjang peran yang dimainkanпyа.

\section{METODE YANG DIGUNAKAN}

Agar supaya aktivitas seni tersebut tidak membosankan, tetap menarik dan mengenai sasaran, maka penyampaian materi perlu dilakukan dengan berbagai metode, yaitu antara lain:

Pertama, Pengamatan. Melalui metode ini seseorang diajak untuk mengenali, membedakan, menggambarkan, dan menggolongkan objek dengan menggunakan seluruh indra yang diperiukan, kemudian mengutarakan apa yang diperolehnya, apa yang dirasakan dan apa yang dipikirkan tentang objek yang diamatinya. Setelah itu bisa diminta untuk mengekspresikan dalam media tertentu (misalnya gambar, karya tempel, puisi atau yang lain).

Kedua Melakukan Intepretasi. Melalui aktivitas ini seseorang diajak untuk menghu- 
bungkan antara satu pengamatan dengan pengamatan lain sehingga terjadi pola untuk menemukan maksud hubungan tersebut. Misalnya, menginterpretasikan syair lagu dan menghubungkan dengan konteks waktu lagu tersebut dibuat.

Ketiga, Bermain Peran. Metode ini berfungsi sebagai wahana untuk lebih memahami kedudukan dan peran orang lain. Melalui metode ini seseorang dilath untuk menghadapi kehidupan nyata yang memiliki peran dan fungsi yang komplek. Misalnya, seseorang diminta untuk berperan sebagai penyanyi pada seni suara dan orang lain sebagai penonton yang berisik. Setelah itu mereka saling berbagi rasa tentang apa yang dialami ketika berperan sebagaimana masing-masing tokoh yang diperankannya.

Keempat, Katarsis. Katarsis adalah pembersihan sistem energi yang terkurung. yang terjadi apabila ekspresi emosi dikendalikan. Ada dua jenis katarsis. Pertama adalah katarsis fisik. Katarsis ini merupakan setiap aktivitas yang menggunakan seluruh energi yang dihasilkan oleh perubahan fisik yang menyertai emosi dan menimbukan suatu kelegaan bagi energi dan memulihkan keseimbangan. Termasuk dalam katarsis fisik adalah menyibukkan diri, tertawa dan menangis.

Katarsis yang kedua adalah katarsis mental. Uhtuk mencapai katarsis mental seseorang harus mengubah sikap terhadap situasi yang menimbulkan emosi mereka. Caranya adalah dengan diskusi, pengkajian masalah atau identifikasi. Teknik katarsis ini biasanya digunakan di awal-awal pertemuan suatu terapi, karena fungsinya memang menciptakan suasana bebas dan aman untuk ekspresi diri.

\section{PENUTUP}

Demikian, ternyata seni juga mempunyai nilai edukasi dan manfaat yang tinggi bagi kehidupan. Dengan seni orang lebih bebas mengekspresikan diri, mengenali dan memahami emosi. Dengan seni seseorang terangsang untuk berkreasi, melakukan daya cipta, daya pikir, inovasi, kepekaan dan ketangkasan yang akan berguna untuk melakukan sesuatu yang bersifat analitis. Melalui ekspresi emosi dan seni orang belajarempati dan kemudian menempatkan diri. Lebih dari itu ternyata secara psikologis seni ini merupakan teknik proyeksi yang enak dilakukan, sehingga ketika seseorang ingin mengungkapkan perasaan, sikap dan kepribadiannya ia tidak perlu takut dan canggung karena seni merupakan media yang sah digunakan oleh siapa saja yang ingin berbagi. Keberanian berbagi ini merupakan indikasi adanya sikap peduli terhadap keberadaan dan rasa orang lain. Sikap seperti ini merupakan salah satu modal untuk berperilaku serba pas secara sosial Sedangkan kemampuan berperilaku pas secara sosial ini adalah merupakan kemampuan bergaul yang baik salah satu ciri dari dimilikinya kecerdasan emosi. Oteh karena itu secara tidak langsung, seni berperan sebagai wahana untuk menajamkan rasa dan memintarkan emosi.

\section{DAFTAR PUSTAKA}

Goleman, D. 1997. KecerdasanEmosional, Jakarta: PT. Gramedia Pustaka Utama.

Hurlock, E.B. 1988. Perkembangan Anak (jilid 1), Jakanta: Penerbit Erlangga.

Kunarto, 1966. Hati Nurani Polisi. Harian Kompas, 1 Juli (halm. 4).

Murbandono, L. 1966. Kedunguan Perasaan. Harian Kompas, 27 Juni (halm. 4). 
Sitaresmi, S. 1997. Seni dalam Kehidupan Seorang Muslim. Sakinah, September 1997 (haim. 8-12).
Sukadji, S. 1986. Kaluarga dan Koborsihan Pendidikan. Jakarta: Unit Produksi dan Distribusi Alat Tes. Fakultas Psikologi Indonesia. 